\title{
ESTIMATION OF SURFACE RUNOFF IN NALLUR AMANIKERE WATERSHED USING SCS-CN METHOD
}

\author{
Sindhu D ${ }^{1}$, B L Shivakumar ${ }^{2}$, A. S Ravikumar ${ }^{3}$ \\ ${ }^{1,2}$ Department of Civil Engineering, R. V. College of Engineering, Bangalore-560059 \\ ${ }^{3}$ Department of Civil Engineering, UVCE, Bangalore University, Jnanabharathi, Bangalore-560056 \\ sindhud@rvce.edu.in, shivakumarbl@rvce.edu.in,as_ravik@yahoo.com
}

\begin{abstract}
The development of watershed aims at productive utilization of all the available natural resources in the entire area extending from ridge line to stream outlet. The per capita availability of land for cultivation has been decreasing over the years. Therefore, water and the related land resources must be developed, utilized and managed in an integrated and comprehensive manner. Remote sensing and GIS techniques are being increasingly used for planning, management and development of natural resources. The study area, Nallur Amanikere watershed geographically lies between $11^{\circ} 38^{\prime}$ and $11^{\circ} 52^{\prime} \mathrm{N}$ latitude and $76^{\circ} 30^{\prime}$ and $76^{\circ} 50^{\prime}$ E longitude with an area of $415.68 \mathrm{Sq} . \mathrm{km}$. The thematic layers such as land use/land cover and soil maps were derived from remotely sensed data and overlayed through ArcGIS software to assign the curve number on polygon wise. The daily rainfall data of six rain gauge stations in and around the watershed (2001-2011) was used to estimate the daily runoff from the watershed using Soil Conservation Service - Curve Number (SCS-CN) method. The runoff estimated from the SCS-CN model was then used to know the variation of runoff potential with different land use/land cover and with different soil conditions.
\end{abstract}

Keywords: Watershed, Nallur watershed, Surface runoff, Rainfall-Runoff, SCS-CN, Remote Sensing, GIS. $* * *$

\section{INTRODUCTION}

A watershed is the area covering all the land contributes runoff water to a common point. It is a natural physiographic or ecological unit composed of interrelated parts and function. Each watershed has definite characteristics such as size, shape, slope, drainage, vegetation, geology, soil, geomorphology, climate and land use. Watershed management implies the proper use of all land and water resources of a watershed for optimum production with minimum hazard to natural resources. Runoff is one of the important hydrologic variables used in the water resources applications and management planning. Estimation of surface runoff is essential for the assessment of water yield potential of the watershed, planning of water conservation measures, recharging the ground water zones and reducing the sedimentation and flooding hazards downstream. Also, it is an important and essential prerequisite of Integrated Watershed Management [7]. Remote Sensing and GIS techniques are being increasingly used for planning, development and management of natural resources. GIS in particular help in integrating various data sets and perform spatial analysis for decision making. GIS and remote sensing are presently being used for solving environmental problems like degradation of land by water logging, soil erosion, deforestation, changes in ecological parameters and many more. Jasrotia et al., [4] used a mathematical model to estimate rainfall, runoff in conjunction with remote sensing data and GIS using SCS CN method and runoff potential map.
Ashish Pandey et al., [1] estimated the runoff from SCS curve number model modified for Indian condition by conventional data base and GIS for Dikrong river basin. Amutha et al., [2] showed that estimation of runoff by SCS-CN method integrated with GIS can be used in watershed management effectively. Somashekar et al.,[6] estimated surface runoff of Hesaraghatta watershed. The analysis was carried using IRSID LISS III satellite images in the form of FCC using SCS curve number method and found that the runoff estimated by SCS method shown reasonable good result.

\section{STUDY AREA}

The study area, Nallur Amanikere watershed is located in Chamarajnagar district and geographically lies between $11^{\circ} 38^{\prime}$ and $11^{\circ} 52^{\circ} \mathrm{N}$ latitude and $76^{\circ} 30^{\prime}$ and $76^{\circ} 50^{\prime} \mathrm{E}$ longitude covering an area of $415.68 \mathrm{Sq} . \mathrm{km}$ as delineated from Survey of India (SOI) toposheet numbers 58A/9, 58A/10, 58A/13 and $58 \mathrm{~A} / 14$ on 1:50000 scale. Maximum length and width of watershed are $34.97 \mathrm{~km}$ and $21.91 \mathrm{~km}$ respectively. Fig.1 shows the location map of the study area. The study area is characterized by an undulating landscape and mountain ranges covered with vast forests. The highest relief in the watershed is found to be $1451 \mathrm{~m}$ and the lowest relief is $762 \mathrm{~m}$ above the mean sea level. The overall relief of the watershed is found to be $0.689 \mathrm{~km}$. The area comprises of the land derived from granite gneisses and charnockite. The soils in the watershed are loamy skeletal, clayey skeletal, fine and fine loamy and 
isohyperthermic. Rainfall in the study area is highly erratic. The average annual rainfall for 11 years (2001-2011) found to be $839.7 \mathrm{~mm}$. Since the study area chosen is an ungauged watershed an attempt was made to estimate runoff by SCS-CN model, obtaining model parameters by integrating the thematic maps prepared using SOI topomaps and remotely sensed data on 1: 50,000 scale and analysing the thematic maps through GIS software.

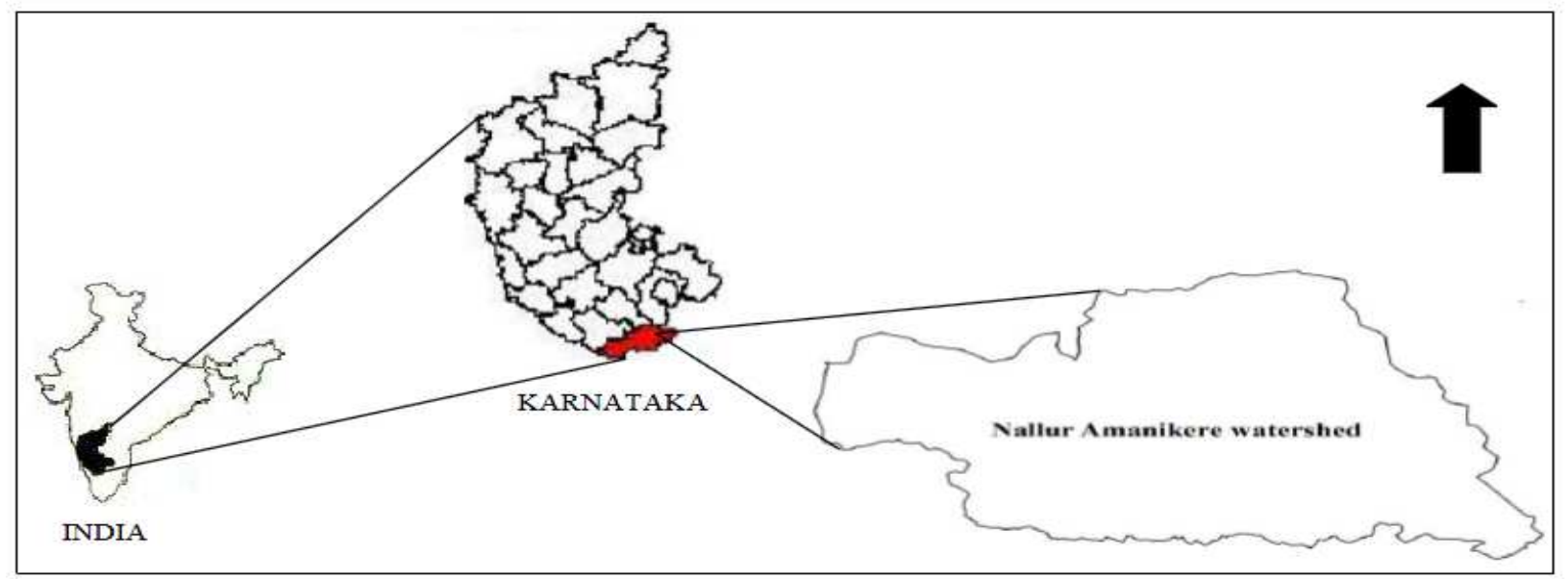

Fig.1 Location map of study area

\section{METHODOLOGY}

SOI toposheet numbers 58A/9, 58A/10, 58A/13 and 58A/14 on 1:50000 scale were used for delineating the watershed boundary and preparation of base map, drainage map. In order to know the different natural resources, terrain conditions, etc. in the study area, toposheets along with the satellite data was used to prepare different thematic maps, updation of drainage, land use/ land cover, soil map. Fig. 2 shows the methodology followed to estimate runoff using SCS Curve Number model. Figs. 3(a), 3(b), 3(c) shows the drainage map, land use/ land cover map, soil map of Nallur Amanikere watershed. Daily rainfall data of six rain gauge stations in and around the watershed for a period of 2001 to 2011 was used for estimation of runoff. Runoff was estimated with the aid of hydrological model using USDA (United States Department for Agriculture) methodology for estimation of surface runoff using SCS (Soil Conservation Service) Curve Number model.

\subsection{SCS Curve Number Model}

The curve number method (Soil Conservation Services, SCS, 1972) also known as the hydrologic soil cover complex method, is a versatile and widely used procedure for runoff estimation. This method includes several important properties of the watershed namely soil permeability, land use and antecedent soil water conditions which are taken into consideration. To estimate the curve number, depth of runoff the land use/land cover and hydrological soil group map showing hydrologic soil groups prepared from IRS satellite data were integrated.

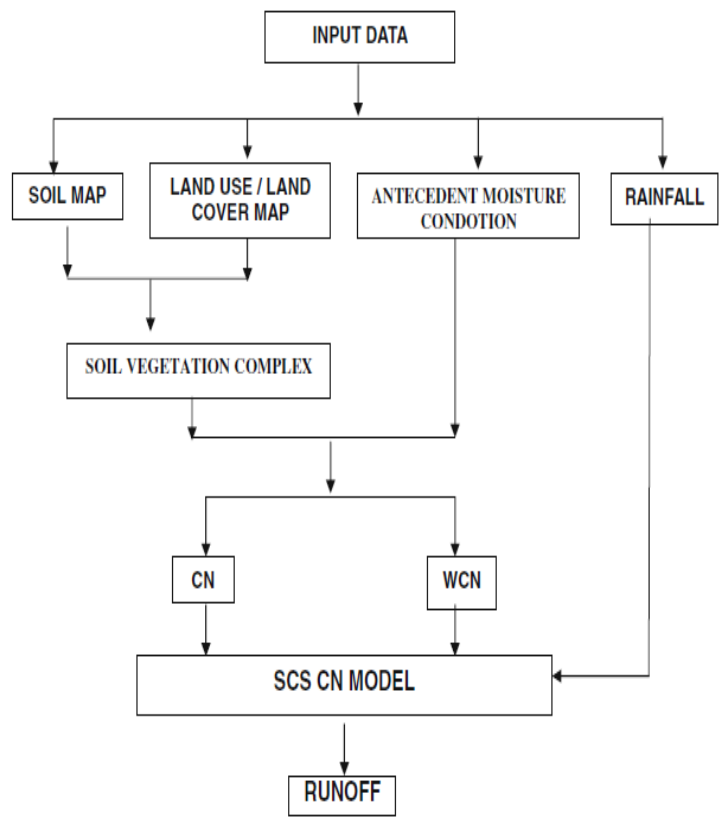

Fig. 2 Methodology to estimate surface runoff by SCS CN model 

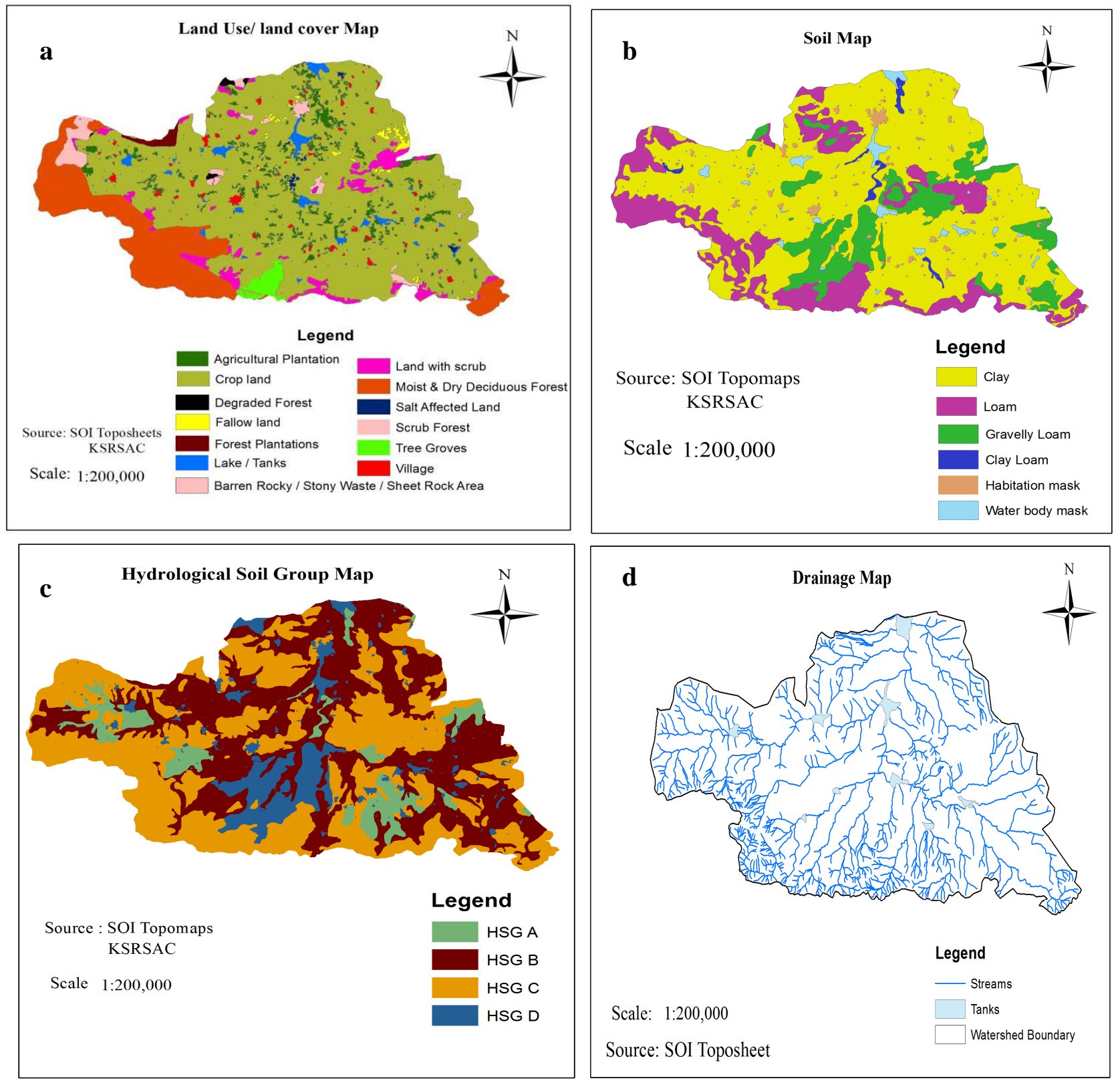

Fig. 3 (a) Drainage map; (b) Land use/ land cover map;

(c) Soil map; (d) Hydrological Soil Group map of Nallur Amanikere watershed

\subsection{Runoff Volume}

Surface runoff is mainly controlled by the amount of rainfall, initial abstraction and moisture retention of the soil. The SCS curve number method is based on the water balance equation and two fundamental hypotheses which are stated as, ratio of the actual direct runoff to the potential runoff is equal to the ratio of the actual infiltration to the potential infiltration, and the amount of initial abstraction is some fraction of the potential infiltration.

$$
\begin{aligned}
& \frac{Q}{\left(P-I_{a}\right)}=\frac{F}{S} \\
& F=\left(P-I_{a}\right)-Q
\end{aligned}
$$

Substituting eq. (2) in eq. (1) and by solving;

$$
Q=\frac{\left(P-I_{a}\right)^{2}}{\left(P-I_{a}\right)+S}
$$


where, $\mathrm{Q}=$ actual runoff $(\mathrm{mm}), \mathrm{P}=$ rainfall $(\mathrm{mm}), \mathrm{I}_{\mathrm{a}}=$ initial abstraction, which represents all the losses before the runoff begins and is given by the empirical equation

$$
I_{a}=0.2 S
$$

Substituting eq. (4) in eq. (3); the eq. (3) becomes

$$
Q=\frac{(P-0.2 S)^{2}}{(P+0.8 S)}
$$

$\mathrm{S}=$ the potential infiltration after the runoff begins given by following equation

$$
S=\frac{25400}{C N}-254
$$

Where $\mathrm{CN}$ is Curve Number and estimated using antecedent moisture condition and hydrological soil group.

\subsection{Antecedent Moisture Condition (AMC)}

Antecedent Moisture Condition (AMC) refers to the water content present in the soil at a given time. It is determined by total rainfall in 5 day period preceding a storm. The AMC value is intended to reflect the effect of infiltration on both the volume and rate of runoff according to the infiltration curve. An increase in index means an increase in the runoff potential. SCS developed three antecedent soil-moisture conditions and labeled them as I, II, III, according to soil conditions and rainfall limits for dormant and growing seasons. Classification

\begin{tabular}{|c|c|c|c|}
\hline \multirow{2}{*}{$\begin{array}{l}\text { AMC } \\
\text { Class }\end{array}$} & \multirow{2}{*}{ Description of soil condition } & \multicolumn{2}{|c|}{ Total five day antecedent rainfall (mm) } \\
\hline & & Dormant season & Growing season \\
\hline I & $\begin{array}{l}\text { Soils are dry but not to the wilting point; satisfactory } \\
\text { cultivation has taken place. }\end{array}$ & $<12.7 \mathrm{~mm}$ & $<35.56 \mathrm{~mm}$ \\
\hline II & Average conditions. & $12.7-27.94 \mathrm{~mm}$ & $35.56-53.34 \mathrm{~mm}$ \\
\hline III & $\begin{array}{l}\text { Heavy rainfall or light rainfall and low temperatures } \\
\text { have occurred within last } 5 \text { days; Saturated soils. }\end{array}$ & $>27.94 \mathrm{~mm}$ & $53.34 \mathrm{~mm}$ \\
\hline
\end{tabular}
of Antecedent Moisture Condition is shown in Table 1.

Table 1 Classification of Antecedent Moisture Conditions (AMC)

\subsection{Hydrological Soil Group (HSG) Classification}

SCS developed soil classification system that consists of four groups, which are identified as A, B, C, and D according to their minimum infiltration rate. Table 2 shows the hydrological soil group classification. $\mathrm{CN}$ values were determined from hydrological soil group and antecedent moisture conditions of the watershed. The Curve Number values for AMC-I and AMC-II were obtained from AMC-II (Chow et al. 1988) [3] by the method of conservation. Runoff curve numbers (AMC II) for hydrologic soil cover complex are shown in Table 3. Fig. 3(d) shows the Hydrological Soil Group map of Nallur Amanikere watershed.

Table 2 Hydrological Soil Group Classification (Mc. Cuen, 1982) [5]

\begin{tabular}{|c|l|c|}
\hline $\begin{array}{c}\text { Soil } \\
\text { Group }\end{array}$ & \multicolumn{1}{c|}{ Description } & $\begin{array}{c}\text { Minimum Infiltration } \\
\text { rate }(\mathrm{mm} / \mathrm{hr})\end{array}$ \\
\hline A & $\begin{array}{l}\text { Soils in this group have a low runoff potential (high-infiltration rates) even } \\
\text { when thoroughly wetted. They consist of deep, well to excessively well- } \\
\text { drained sands or gravels. These soils have a high rate of water transmission. }\end{array}$ & $7.62-11.43$ \\
\hline B & $\begin{array}{l}\text { Soils in this group have moderate infiltration rates when thoroughly wetted } \\
\text { and consists chiefly of moderately deep to deep, well-drained to moderately } \\
\text { well-drained soils with moderately fine to moderately coarse textures. These } \\
\text { soils have a moderate rate of water transmission. }\end{array}$ & $3.81-7.62$ \\
\hline C & $\begin{array}{l}\text { Soils have slow infiltration rates when thoroughly wetted and consist chiefly } \\
\text { of soils with a layer that impedes the downward movement of water, or soils } \\
\text { with moderately fine-to fine texture. These soils have a slow rate of water } \\
\text { transmission. }\end{array}$ & $1.27-3.81$ \\
\hline
\end{tabular}




\begin{tabular}{|c|c|c|}
\hline $\mathrm{D}$ & $\begin{array}{l}\text { Soils have a high runoff potential (very slow infiltration rates) when } \\
\text { thoroughly wetted. These soils consist chiefly of clay soils with high swelling } \\
\text { potential, soils with a permanent high-water table, soils with a clay layer near } \\
\text { the surface, and shallow soils over nearly impervious material. These soils } \\
\text { have a very slow rate of water transmission. }\end{array}$ & $0-1.27$ \\
\hline
\end{tabular}

Table 3 Runoff curve numbers (AMC II) for hydrologic soil cover complex

\begin{tabular}{|c|l|c|c|c|c|}
\hline \multirow{2}{*}{ S1 No. } & \multirow{2}{*}{ Land use } & \multicolumn{4}{|c|}{ Hydrologic Soil Group } \\
\cline { 3 - 6 } & & A & B & C & D \\
\hline 1 & Agricultural land without conservation (Kharif) & 72 & 81 & 88 & 91 \\
\hline 2 & Double crop & 62 & 71 & 88 & 91 \\
\hline 3 & Agriculture Plantation & 45 & 53 & 67 & 72 \\
\hline 4 & Land with scrub & 36 & 60 & 73 & 79 \\
\hline 5 & Land without scrub (Stony waste/ rock out crops) & 45 & 66 & 77 & 83 \\
\hline 6 & Forest (degraded) & 45 & 66 & 77 & 83 \\
\hline 7 & Forest Plantation & 25 & 55 & 70 & 77 \\
\hline 8 & Grass land/pasture & 39 & 61 & 74 & 80 \\
\hline 9 & Settlement & 57 & 72 & 81 & 86 \\
\hline 10 & Road / railway line & 98 & 98 & 98 & 98 \\
\hline 11 & River / stream & 97 & 97 & 97 & 97 \\
\hline 12 & Tanks without water & 96 & 96 & 96 & 96 \\
\hline 13 & Tank with water & 100 & 100 & 100 & 100 \\
\hline
\end{tabular}

(Source: Chow et al, 1988)[3]

\section{RESULTS AND DISCUSSION}

The study area constitutes different land use/ land cover, about $4.56 \%$ of the area is occupied by agricultural plantation, 17.26 $\%$ of area is covered by forest , $67.94 \%$ of area by crop land, $0.77 \%$ of area by fallow land and remaining $9.47 \%$ of the area is occupied by others such as, water body, settlement, land with scrub and tanks. In general, among the different land cover types the crop land plays the major role for the direct surface runoff. According to Drought monitoring cell (DMC) Bangalore, the mean annual rainfall of the study area for the period between 2001 and 2011 is $5018.50 \mathrm{~mm}$ with a maximum rainfall of $7419.40 \mathrm{~mm}$ in 2005 and a minimum of $2455.20 \mathrm{~mm}$ in 2003. From SCS Curve number, the maximum runoff for the watershed was estimated to be $1869.57 \mathrm{~mm}$ in the year 2005 and minimum runoff of $263.68 \mathrm{~mm}$ in the year 2003. Table 4 shows the annual rainfall and runoff for Nallur Amanikere watershed for the period 2001 to 2011. Fig. 4 shows the rainfall runoff relationship for Nallur Amanikere watershed. The rainfall and runoff are strongly correlated with correlation coefficient ( $\mathrm{r}$ ) value being 0.85 .

Table 4 Annual Rainfall and runoff
\begin{tabular}{|c|c|c|}
\hline for watershed \\
\hline Year & $\begin{array}{c}\text { Rainfall } \\
(1 \mathrm{~m})\end{array}$ & $\begin{array}{c}\text { Runoff } \\
(\mathrm{mm})\end{array}$ \\
\hline 2001 & 3589.70 & 680.09 \\
\hline 2002 & 3078.33 & 373.64 \\
\hline 2003 & 2455.20 & 263.68 \\
\hline 2004 & 5808.30 & 1015.08 \\
\hline 2005 & 7419.40 & 1869.57 \\
\hline 2006 & 4673.90 & 942.11 \\
\hline 2007 & 5896.30 & 1276.87 \\
\hline 2008 & 5911.90 & 1343.78 \\
\hline 2009 & 5404.60 & 1158.63 \\
\hline 2010 & 5863.60 & 809.02 \\
\hline 2011 & 5018.50 & 843.17 \\
\hline
\end{tabular}

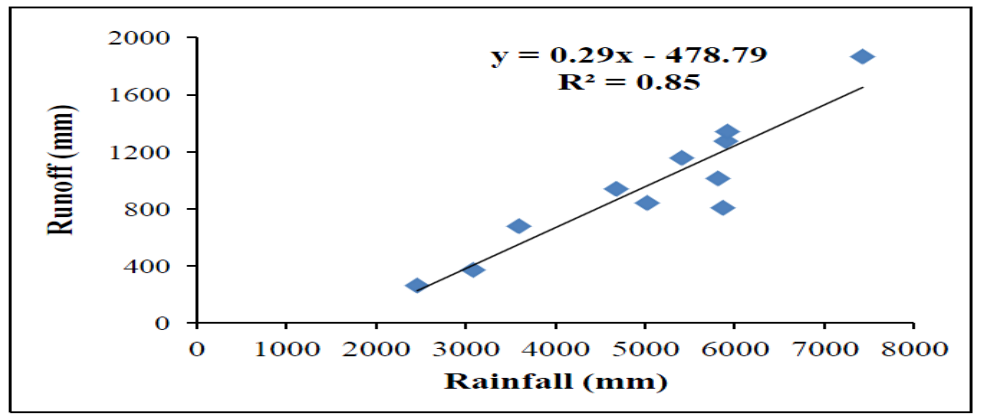

Fig 4 Rainfall Runoff relationship for Nallur Amanikere watershed 


\section{CONCLUSIONS}

The estimation of runoff using GIS based SCS curve number method can be used in watershed management effectively. All the factors in SCS model are geographic in character. Due to the geographic nature of these factors, SCS runoff model can be easily molded into GIS. The study demonstrates the importance of remotely sensed data in conjunction with GIS to derive the model parameter to estimate surface runoff from the ungauged watershed. Results obtained clearly shows the variation in runoff potential with different land use/land cover and with different soil conditions. Based on the digital database creation, conservation techniques such as percolation pond, check dam etc., can be recommended for better management of land and water resources for sustainable development of the watershed.

\section{REFERENCES}

[1] Ashish Pandey and Dabral. P.P. (2004), "Estimation of Runoff for Hilly Catchment Using Satellite Data", Journal of Indian Society of Remote Sensing, Vol. 32, No. 2, pp. 236-240.

[2] Amutha R, Porchelvan P (2009), "Estimation of Surface Runoff in Malattar Sub-Watershed using SCSCN method", Journal of Indian Society of Remote Sensing, Vol. 37, pp.291-304.

[3] Chow, V. T., Maidment, D. R., and Mayse, W. (1988). "Applied Hydrology", New York:Mc Graw Hill.

[4] Jasrotia A. S., Dhiman S. D., and Aggarwal S. P. (2002). "Rainfall-runoff and soil erosion modeling using remote sensing and GIS technique - A case study on tons watershed", Journal of Indian Society of Remote Sensing, Vol.30(3), pp. 167-180.

[5] Mc. Cuen, R. H. (1982). "A guide to hydrologic analysis using SCS methods", Englewood Cliffs: Prentice Hall Inc.

[6] Somashekar R. K., Ravikumar P., Sowmya S. V., Mubhashir Aziz Dar, Ravikumar A. S., (2011) "Runoff estimation and morphometric analysis for Hesaraghatta watershed using IRS-ID LISS III FCC satellite data", Journal of Indian Society of Remote Sensing, Vol. 39,pp. 95-106.

[7] Subramanya K. (2008), "Engineering Hydrology", Publisher Tata McGraw Hill, 3rd edition, pp.139-195.

[8] USDA-SCS-CN Method (1972), "A Method for Estimating Volume and Rate of Runoff in Small watersheds"; SCS-TP-149, U.S. Department of Agriculture, Soil Conservation Service, Washington, DC. 